\title{
KARAKTERISASI EMPAT POPULASI IKAN GURAMI (Osphronemus goramy Lac.) DAN PERSILANGANNYA BERDASARKAN METODE TRUSS MORFOMETRIKS
}

\author{
Suharyanto\#, Rita Febrianti, dan Sularto \\ Balai Penelitian Pemuliaan Ikan
}

\begin{abstract}
ABSTRAK
Tahap awal yang dilakukan dalam rangka pembentukan populasi ikan gurami cepat tumbuh adalah koleksi dan karakterisasi populasi-populasi ikan gurami yang akan digunakan sebagai sumber genetik pembentukan varietas tersebut. Kegiatan ini dilakukan untuk mengevaluasi keragaman morfologi dan hubungan kekerabatan empat populasi ikan gurami, yaitu Jambi ()), Kalimantan Selatan (K), Majalengka (M), dan Tasikmalaya (T). Metode truss morfometrik digunakan untuk karakterisasi morfologi dilanjutkan dengan analisis komponen utama (principal component analysis) dan analisis pengelompokan (cluster analysis). Hasil karakterisasi menunjukkan bahwa diagram pencar populasi ikan gurami tanpa melihat jenis kelamin menunjukkan adanya pengelompokan populasi menjadi dua kelompok, yaitu kelompok pertama adalah persilangan JxM dan MxK, sedangkan kelompok kedua terdiri atas persilangan JxK, KxJ, TxJ, KxM, MxJ, KxT, galur murni $\mathrm{KxK}, J \mathrm{xJ}, \mathrm{MxM}$, dan TxT. Hal tersebut terjadi pula pada populasi jantan. Populasi betina menunjukkan JxK dan M xK terpisah berdasarkan karakter A2 (dahi-pangkal sirip punggung) dan A3 (pangkal sirip punggung-pangkal sirip perut). Indeks kesamaan tertinggi dalam 12 populasi diperoleh pada populasi Jambi dan Majalengka berturut-turut sebesar $94,00 \%$ dan $92,00 \%$ sedangkan indeks kesamaan terendah diperoleh pada populasi TJ sebesar $72,00 \%$ Ikan gurami ukuran konsumsi terdapat empat kelompok besar berdasarkan bentuk badannya. Dua kelompok pada galur murni menunjukkan populasi galur murni Kalimantan, Majalengka, dan Tasikmalaya kekerabatannya dekat, akan tetapi dengan Jambi memiliki kekerabatan yang jauh. Dua kelompok lainnya pada populasi persilangan, yaitu: persilangan JXM dan M XK dan kelompok lainnya adalah persilangan KxJ, KxM, JxK, TxJ, MxJ, dan KxT. Populasi galur murni dan persilangan memiliki jarak genetik yang jauh, sehingga populasi galur murni dan persilangan itu berbeda.
\end{abstract}

KATA KUNCl: ikan gurami; karakterisasi; truss morfometrik

ABSTRACT: Characterization of four populations of giant gourami (Osphronemus goramy Lac.) and cross breeding from South Kalimantan, Jambi, Majalengka, and Tasikmalaya based on truss morphometric method. By: Suharyanto, Rita Febrianti, and Sularto

The first step in breeding program towards generating fast-growing strain of giant gourami is the collection and characterization of giant gourami populations have been used as a genetic source. Giant gourami had been collected from South Kalimantan, Jambi, Majalengka, and Tasikmalaya. The aim of this experiment was to determine the morphological diversity among these collected populations using truss morphometric method. Principal component analysis followed by cluster analysis were used to identify the pattern of morphological variabilityamong populations and varieties. The results showed that dendrogram populations of giant gourami regardless of gender showed a grouping of some of the population into two groups: the first group was J $\times M$ and $M \times K$ crosses, while the second population consisted of: Jambi Kalimantan (J K K), Kalimantan Jambi (KXJ), Tasikmalaya Jambi (Tx J), Kalimantan Majalengka (KX M), Majalengka Jambi (M X J), Kalimantan Tasikmalaya ( $\mathrm{X} \times \mathrm{T})$, purebred Kalimantan (K× K), Jambi $(\mathrm{X} \mathrm{J})$, Majalengka $(\mathrm{M} \times \mathrm{M})$, and Tasikmalaya $(T \times T)$. This was true for the male population. Female population showed $\mathrm{J} \times \mathrm{K}$ and $\mathrm{M} \times \mathrm{K}$ apart, the difference lies in the character of the forehead-base of the dorsal fin (A2) and the base of the dorsal fin-fin base stomach (A3). The highest similarity index was found Jambi $(94.00 \%$ Majalengka $(92.00 \%$ populations, while the lowest similarity index was $T \times J(72.00 \%$. At market size of the consumption of giant gourami there are four major groups, based on the shape of the body. Two groups on purestrains showed a population

\footnotetext{
\# Korespondensi: Balai Penelitian Pemuliaan Ikan.

Jl. Raya 2 Pantura Sukamandi, Subang 41263, Jawa Barat,

Indonesia. Tel.: + (0260) 520500

E-mail: suhar.yant083@ymail.com
} 
of pure lines Kalimantan, Majalengka, and Tasikmalaya close kinship, but Jambi had a distant kinship. Two other groups in the population crosses, namely: cross $\mathrm{J} \times \mathrm{M}$ and $\mathrm{M} \times \mathrm{K}$ and the other group was a cross $\mathrm{K} \times \mathrm{J}, \mathrm{M} \times \mathrm{K}, \mathrm{J} \times \mathrm{K}$, $T \times J, M \times J$, and $K \times T$. The population of pure lines and crosses had a genetic distance away, so that the population of pure lines and crosses were different.

\section{KEYWORDS: giant gourami; characterization; truss morphometric}

\section{PENDAHULUAN}

Ikan gurami (Osphronemus goramy Lac.) merupakan ikan air tawar yang banyak tersebar hampir di seluruh wilayah Indonesia. Ikan gurami berasal dari perairan daerah Sunda (Jawa Barat, Indonesia), dan menyebar ke Malaysia, Thailand, dan Australia. Ikan gurami sangat peka terhadap suhu dingin, sehingga hanya dapat dipelihara pada dataran rendah sampai sedang dengan ketinggian 50-600 m dpl. Ikan gurami memiliki kemampuan mengambil oksigen dari udara karena adanya labirin yang terletak di atas atau di belakang insang. Populasi-populasi ikan gurami itu di antaranya adalah: soang, Jepang, Paris, bastar, dan porselen telah digunakan dalam budidaya di Indonesia (Suseno et al., 2000; Sudarto, 1989). Identiflkasi populasi gurami menggunakan analisis morfometrik dan biokimia telah dilakukan (Soewardi et al., 1995; Soewardi, 1995; Kusmini et al., 2000; Suseno et al., 2000). Menurut Nugroho et al. (1993), terdapat perbedaan morfologi dan potensi pertumbuhan beberapa populasi ikan gurami.

Permasalahan utama pada budidaya ikan gurami adalah pertumbuhan yang lambat (Bittner et al., 1989). Dalam rangka mengatasi permasalahan ini dibutuhkan penyediaan benih ikan gurami yang mempunyai laju pertumbuhan yang cepat dalam jumlah yang mencukupi. Induk ikan gurami dipilih dari daerah Kalimantan Selatan, Jambi, Majalengka, dan Tasikmalaya. Hal itu dikarenakan, induk dari daerah tersebut merupakan induk gurami yang tumbuh endemik. Selain itu juga, belum ada informasi mengenai karakteristik dari keempat varietas gurami tersebut. Oleh karena itu, dengan mengetahui karakteristik dari masing-masing populasi dapat digunakan untuk menentukan langkah-langkah yang diambil dalam rangka menghasilkan benih unggul.

Banyaknya genotipe ikan gurami memberikan peluang untuk dimanfaatkan dalam sebuah program pemuliaan (Ariyanto et al., 2011). Keragaman genetik yang berupa strain dalam spesies ikan gurami untuk tujuan pemuliaan membutuhkan karakterisasi dari strain atau varietas tersebut. Teknik karakterisasi yang paling mudah dilakukan adalah dengan pengamatan secara morfologi. Salah satu teknik pengamatan morfologi yang dapat memberikan hasil dengan akurasi cukup tinggi adalah pengukuran truss morfometrik. Menurut Strauss \& Bookstein (1982), metode truss menghasilkan karakterisasi geometrik bentuk badan ikan secara lebih sistematis dan menunjukkan peningkatan kemampuan dalam mengidentifikasi perbedaan-perbedaan bentuk badan ikan. Morfometrik merupakan ukuran bagian-bagian tertentu dari badan ikan (measuring methods). Karakter morfometrik yang sering digunakan pada saat diukur adalah panjang total, panjang standar, panjang cagak, tinggi lebar badan, tinggi, dan badan sirip, serta diameter mata (Hubbs \& Lagler 1958; Parin 1999). Beberapa kegiatan karakterisasi menggunakan metode truss terbukti mampu memberikan hasil yang lebih baik dibandingkan karakterisasi menggunakan metode konvensional antara lain pada ikan Indian mackerel, Rastrelliger kanagurta (Jayasankar et al., 2004), po pulasi ikan Labeo victorianus (Rutaisire et al., 2005), ikan nila (Eknath et al., 1991; Ariyanto \& Imron, 2002), ikan mas (Imron et al., 2000), ikan salmon (Winans, 1984; Swain \& Holtby, 1989; Swain et al., 1991). Penelitian terdahulu (Soewardi et al., 1995; Suseno et al., 2000; Kusmini et al., 2000) telah melakukan karakterisasi secara genetik dan morfometrik pada ikan gurami. Kajian morfometrik secara menyeluruh menggunakan truss morfometrik dilakukan untuk melengkapi informasi yang ada pada penelitian sebelumnya. Penelitian ini dilakukan untuk mengetahui karakter morfometrik populasi ikan gurami yang berasal dari Kalimantan Selatan, Jambi, Majalengka, dan Tasikmalaya, serta mengetahui jarak genetik dan kekerabatan berdasarkan tingkat keragaman dan kemiripannya.

\section{BAHAN DAN METODE}

\section{Ikan Uji}

Penelitian dilakukan di Balai Penelitian Pemuliaan Ikan, Sukamandi pada tahun 2015. Ikan yang digunakan adalah ikan gurami hasil persilangan ikan-ikan gurami yang berasal dari Kalimantan Selatan (K), Jambi (J), Majalengka (M), dan Tasikmalaya (T) yang berumur 16 bulan, sebanyak 600 ekor dengan bobot berkisar antara 732,27-1.091,83 g. Masing-masing populasi diambil 50 ekor dan digunakan untuk analisis truss morfometrik. Skema persilangan adalah sebagai berikut: 


\begin{tabular}{|c|c|c|c|c|c|}
\hline & & K & $J$ & M & $\mathrm{T}$ \\
\hline & & KK & $\mathrm{KJ}$ & KM & $\mathrm{KT}$ \\
\hline & & JK & JJ & JM & JT \\
\hline & & MK & MJ & MM & MT \\
\hline & & TK & TJ & TM & TT \\
\hline \multicolumn{6}{|c|}{ Keterangan: } \\
\hline $\mathrm{K}$ & & \multicolumn{4}{|l|}{ Kalimantan } \\
\hline J & & \multicolumn{4}{|l|}{ lambi } \\
\hline M & & \multicolumn{4}{|l|}{ Majalengka } \\
\hline T & & \multicolumn{4}{|l|}{ Tasikmalaya } \\
\hline Hitam & : & \multicolumn{4}{|l|}{ Tidak memijah } \\
\hline
\end{tabular}

Identiflkasi populasi mengacu pada Soewardi (1995). Metode pengukuran dilakukan dengan metode morfometrik dengan cara menentukan titik-titik tertentu sepanjang badan ikan lalu menghubungkan titik-titik tersebut sehingga badan ikan terbagi menjadi beberapa ruang truss. Selanjutnya dilakukan pengukuran panjang terhadap garis-garis di setiap ruang truss. Karakter truss morfometrik induk ikan gurami dilakukan dari delapan titik di sepanjang badan, serta menghasilkan 16 karakter truss (Setijaningsih et al., 2007).

Data semua karakter morfometrik dikonversi ke dalam rasio dengan cara membagi ukuran setiap karakter dengan panjang standar. Data rasio ukuran karakter dianalisis dengan menggunakan program Ky plot, Systat 11, dan SAS. Karakterisasi terhadap populasi ikan gurami dilakukan secara morfologi dengan metode truss morfometrik.

\section{Karakterisasi Morfologi}

Analisis keragaman morfologi antar populasi dilakukan melalui pengukuran secara morfometrik. Sampel diletakkan di atas kertas tahan air dengan bagian kepala berada di sebelah kiri. Titik-titik patokan yang jelas, konsisten, dan homolog dari satu sampel ke sampel lain dipilih di sekitar garis bentuk (outline) badan ikan. Delapan buah titik patokan yang dipilih membagi garis bentuk badan ikan menjadi tiga bidang dan menghasilkan 16 karakter truss. Ikan difoto kemudian jarak antar titik-titik patokan diukur menggunakan program Analysis dengan ketelitian 0,5 $\mathrm{mm}$. Secara lebih jelas titik-titik outliner pada badan ikan disajikan pada Gambar 1.

Berdasarkan titik-titik pada outliner badan ikan tersebut, kemudian dilakukan pengukuran pada 16 karakter truss yang dibentuk. Deskripsi lebih detail mengenai karakter truss yang dianalisis disajikan pada Tabel 1.

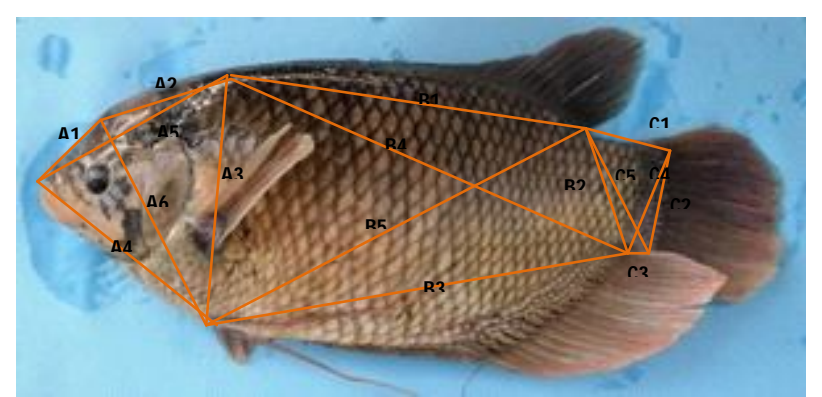

Gambar 1. Lokasi 16 titik yang ditentukan pada garis luar badan ikan untuk memperoleh data truss morfometrik. Titik-titik landmark mengacu kepada (1) ujung mulut, (2) dahi, (3) pangkal sirip punggung, (4) pangkal sirip perut, (5) ujung sirip punggung, (6) ujung sirip anal, (7) pangkal atas sirip ekor, (8) pangkal bawah sirip ekor

Figure 1. Location of 16 points on fish body outliner for truss network data. Landmark points refer to (1) end of upper mouth, (2) forehead (3) base of the dorsal fin, (4) base of the pelvic fins, (5) tip of the dorsal fin, (6) end of anal fin, (7) base on tail fins, (8) below base of tail fin 
Tabel 1. Deskripsi 16 karakter truss morfometrik untuk analisis keragaman antar varietas ikan gurami

Table 1. Description of 16 truss morphometric characters used to explore the body shape variability among the varieties of giant gourami

\begin{tabular}{|c|c|c|}
\hline $\begin{array}{l}\text { Karakter truss } \\
\text { Truss character }\end{array}$ & $\begin{array}{l}\text { Kode } \\
\text { Code }\end{array}$ & $\begin{array}{l}\text { Deskripsi } \\
\text { Description }\end{array}$ \\
\hline \multirow{6}{*}{ Kepala (Head) } & $\mathrm{A} 1$ & $\begin{array}{l}\text { Ujung mulut - dahi } \\
\text { End of upper mouth - forehead }\end{array}$ \\
\hline & $\mathrm{A} 2$ & $\begin{array}{l}\text { Dahi - pangkal sirip punggung } \\
\text { Forehead - origin of dorsal fin }\end{array}$ \\
\hline & A3 & $\begin{array}{l}\text { Pangkal sirip punggung - pangkal sirip perut } \\
\text { Origin of dorsal fin - origin of abdominal fin }\end{array}$ \\
\hline & A4 & $\begin{array}{l}\text { Ujung mulut- pangkal sirip perut } \\
\text { End of upper mouth - origin of abdominal fin }\end{array}$ \\
\hline & A5 & $\begin{array}{l}\text { Dahi - pangkal sirip perut } \\
\text { Forehead - origin of abdominal fin }\end{array}$ \\
\hline & A6 & $\begin{array}{l}\text { Ujung mulut - pangkal sirip punggung } \\
\text { End of upper mouth - origin of dorsal fin }\end{array}$ \\
\hline \multirow{5}{*}{ Badan (Body) } & B1 & $\begin{array}{l}\text { Pangkal sirip punggung - ujung sirip punggung } \\
\text { Origin of abdominal fin - end of dorsal fin }\end{array}$ \\
\hline & B2 & $\begin{array}{l}\text { Ujung sirip punggung - ujung sirip anal } \\
\text { End of dorsal fin - end of anal fin }\end{array}$ \\
\hline & B3 & $\begin{array}{l}\text { Pangkal sirip perut - ujung sirip anal } \\
\text { Origin of abdominal fin - end of anal fin }\end{array}$ \\
\hline & B4 & $\begin{array}{l}\text { Pangkal sirip punggung - ujung sirip anal } \\
\text { Origin of dorsal fin - end of anal fin }\end{array}$ \\
\hline & B5 & $\begin{array}{l}\text { Pangkal sirip perut - ujung sirip punggung } \\
\text { Origin of abdominal fin - end of dorsal fin }\end{array}$ \\
\hline \multirow{5}{*}{ Batang ekor (Caudal fin ) } & $\mathrm{Cl}$ & $\begin{array}{l}\text { Ujung sirip punggung - pangkal atas sirip ekor } \\
\text { End of dorsal fin - end of upper tail }\end{array}$ \\
\hline & $\mathrm{C} 2$ & $\begin{array}{c}\text { Pangkal atas, sirip ekor - pangkal bawah sirip ekor } \\
\text { End of upper tail - end of under tail }\end{array}$ \\
\hline & C3 & $\begin{array}{l}\text { Ujung sirip anal - pangkal bawah sirip ekor } \\
\text { End of anal fin - end of under tail }\end{array}$ \\
\hline & C4 & $\begin{array}{l}\text { Ujung sirip punggung - pangkal bawah sirip ekor } \\
\text { End of dorsal fin - end of under tail }\end{array}$ \\
\hline & C5 & $\begin{array}{l}\text { Ujung sirip anal - pangkal atas sirip ekor } \\
\text { End of dorsal fin - end of upper tail }\end{array}$ \\
\hline
\end{tabular}

Ikan gurami yang diamati sebanyak 12 populasi, yaitu populasi ikan gurami JxK, KXJ, TxJ, KxM, MxJ, KxT, galur murni KxK, JxJ, MxM, dan TxT. Parameter yang diamati adalah: koefisien keragaman (KK), proporsi keragaman, dan indeks kesamaan menggunakan analisis diskriminasi pada ikan gurami secara umum. Parameter diagram pencar dan jarak genetik (dendrogram) juga diamati sampai ke perbedaan jenis kelamin antara jantan $($ male $=M)$ dan betina (female $=F$ ). Identifikasi keragaman bentuk antar populasi harus bebas dari bias yang disebabkan oleh perbedaan ukuran (Imron et al., 2000). Upaya meminimalkan pengaruh keragaman ukuran mengikuti prosedur Edge et al. (1991). Analisis komponen utama (Principal Component Analysis/PCA) atau diagram pencar bertujuan untuk mengidentifikasi pola keragaman antar varietas (Strauss \& Bond, 1990). Analisis pengelompokan atau cluster analysis dilakukan sebagai analisis lanjutan. Analisis ini dilakukan untuk mengetahui pengelompokan masing-masing populasi dan melihat seberapa jauh perbedaan dan kemiripan morfologi antar populasi. Analisis komponen utama dan pengelompokan (clustering) atau dendogram dilakukan dengan program Ky plot dan SYSTATT 11. 
Untuk melihat penyebaran karakter dilakukan dengan Analisis Kanonical, untuk melihat keeratan korelasi dengan Analisis Diskriminan. Untuk melihat jarak genetik antar populasi digunakan program SAS.

\section{HASIL DAN BAHASAN}

Jenis varietas (masing-masing 50 ekor), ukuran ikan dan koefisien keragaman ukuran ikan disajikan pada Tabel 2.

Jumlah sampel untuk analisis morfometrik sebanyak 50 ekor yang diambil secara acak dari setiap populasi. Jumlah sampel ini diharapkan dapat mewakili masingmasing populasi karena ukuran masing-masing populasi relatif seragam. Hal ini ditunjukkan dengan koefisien keragaman populasi gurami yang relatif kecil (< 10\%).

Hasil analisis komponen utama (PCA), menggunakan data truss morfometrik pada 12 populasi sampel ikan gurami disajikan pada Tabel 3. Berdasarkan koefisien skor komponen pada Tabel 3 terlihat bahwa keragaman bentuk badan ikan gurami dipengaruhi oleh karakter-karakter yang tersebar pada karakter yang membentuk kepala, badan, dan batang ekor. Hampir semua karakter yang diuji memberikan kontribusi dalam membedakan bentuk badan ikan gurami. Proporsi keragaman pada ikan gurami disajikan pada Tabel 3.

Karakter-karakter yang berkontribusi membedakan bentuk badan ikan gurami tanpa melihat jenis kelamin terdapat pada bagian kepala, yaitu: A-2 (dahi - pangkal sirip punggung) dan A-6 (ujung mulut - pangkal sirip punggung). Bagian badan ikan gurami yang membedakan karakter adalah B-1 (pangkal sirip punggung - ujung sirip punggung). Bagian batang ekor yang membedakan adalah C-3 (ujung sirip anal - pangkal bawah sirip ekor). Hal tersebut ditunjukkan dari nilai KK yang tinggi (Tabel 3). Karakter-karakter yang mempunyai kontribusi besar terhadap pembedaan bentuk badan ikan gurami adalah bagian kepala, badan, dan bagian belakang (batang ekor). Hal ini sejalan dengan yang dilaporkan pada analisis truss antar strain pada ikan gurami terbesar terletak pada karakter kepala, badan, dan batang ekor (Setijaningsih et al., 2007).

Secara umum, diagram pencar konsisten memperlihatkan pola pengelompokan antar populasi. Diagram pencar populasi ikan gurami tanpa melihat jenis kelamin menunjukkan adanya pengelompokan beberapa populasi menjadi dua kelompok yaitu kelompok pertama populasi persilangan JM dan MK, sedangkan populasi kedua terdiri atas: JK, KJ, TJ, KM, MJ, KT, KK, JJ, MM, dan TT. Sebaran karakter morfometrik individu antara strain ikan uji menunjukkan hubungan kekerabatan antara strain cukup erat. Hal ini ditunjukkan dengan adanya daerah himpitan antara strain yang satu dengan strain lainnya. Kelompok pertama dan kedua dapat dibedakan pada bentuk kepala karakter A-1 (ujung mulut - dahi) dan A-2 (dahi - pangkal sirip punggung). Populasi JM dan JJ memiliki perbedaan yang sangat jauh pada karakter A-1 dan A-2.

Tabel 2. Jenis populasi, ukuran panjang badan, dan koefisien keragaman (KK), dari ikan gurami hasil koleksi (masing-masing 50 ekor)

Table 2. The population, numbers, length, and coefficient of variance (CV) of collected giant gourami (50 individu respectively)

\begin{tabular}{ccc}
\hline $\begin{array}{c}\text { Populasi } \\
\text { Population }\end{array}$ & $\begin{array}{c}\text { Panjang } \\
\text { Length } \mathbf{( c m )}\end{array}$ & $\begin{array}{c}\text { Koefisien keragaman (KK) } \\
\text { Coeffisien covariance (CV) } \\
\text { (\%) }\end{array}$ \\
\hline JK & $31.14 \pm 1.07$ & 3.45 \\
KJ & $31.18 \pm 1.09$ & 3.50 \\
TJ & $31.07 \pm 0.99$ & 3.17 \\
KM & $30.89 \pm 1.35$ & 4.36 \\
MJ & $33.10 \pm 0.88$ & 2.65 \\
JM & $30.80 \pm 1.21$ & 3.94 \\
MK & $29.96 \pm 1.12$ & 3.74 \\
KT & $31.14 \pm 1.29$ & 4.15 \\
KK & $25.61 \pm 0.38$ & 1.49 \\
JJ & $23.23 \pm 0.28$ & 1.19 \\
MM & $25.18 \pm 0.38$ & 1.50 \\
TT & $24.48 \pm 0.25$ & 1.03 \\
\hline
\end{tabular}


Tabel 3. Proporsi keragaman yang dapat dijelaskan oleh empat sumbu utama pertama pada analisis komponen utama menggunakan 16 karakter truss morfometrik pada 12 populasi ikan gurami

Table 3. Score and variability proportion explained by the first four PCs in Principal Component Analysis (PCA) using 16 truss morphometric characters of 12 populations of giant gourami

\begin{tabular}{|c|c|c|c|c|c|c|c|c|c|c|c|c|c|c|c|c|}
\hline \multirow{2}{*}{$\begin{array}{c}\text { Populasi } \\
\text { Populations }\end{array}$} & \multicolumn{16}{|c|}{ Karakter yang diukur (Character measured) } \\
\hline & Al & A2 & A3 & A4 & A5 & A6 & B1 & B2 & B3 & B4 & B5 & $\mathrm{Cl}$ & C2 & C3 & C4 & C5 \\
\hline JK & 0.13 & 0.21 & 0.45 & 0.36 & 0.39 & 0.34 & 0.62 & 0.22 & 0.74 & 0.76 & 0.72 & 0.12 & 0.17 & 0.05 & 0.24 & 0.18 \\
\hline $\mathrm{KJ}$ & 0.13 & 0.22 & 0.41 & 0.34 & 0.36 & 0.33 & 0.5 & 0.2 & 0.62 & 0.63 & 0.61 & 0.13 & 0.15 & 0.05 & 0.22 & 0.17 \\
\hline TJ & 0.13 & 0.21 & 0.43 & 0.35 & 0.38 & 0.32 & 0.6 & 0.21 & 0.71 & 0.73 & 0.69 & 0.12 & 0.16 & 0.05 & 0.23 & 0.17 \\
\hline KM & 0.12 & 0.27 & 0.44 & 0.36 & 0.37 & 0.37 & 0.48 & 0.21 & 0.65 & 0.61 & 0.65 & 0.13 & 0.15 & 0.07 & 0.22 & 0.18 \\
\hline MJ & 0.12 & 0.29 & 0.47 & 0.38 & 0.4 & 0.4 & 0.51 & 0.22 & 0.68 & 0.66 & 0.68 & 0.13 & 0.14 & 0.06 & 0.23 & 0.17 \\
\hline JM & 0.15 & 0.35 & 0.57 & 0.47 & 0.49 & 0.49 & 0.67 & 0.27 & 0.87 & 0.84 & 0.85 & 0.16 & 0.18 & 0.08 & 0.27 & 0.22 \\
\hline MK & 0.15 & 0.4 & 0.6 & 0.48 & 0.49 & 0.53 & 0.64 & 0.27 & 0.89 & 0.83 & 0.87 & 0.17 & 0.18 & 0.09 & 0.28 & 0.23 \\
\hline $\mathrm{KT}$ & 0.12 & 0.33 & 0.5 & 0.38 & 0.4 & 0.43 & 0.52 & 0.22 & 0.73 & 0.68 & 0.72 & 0.14 & 0.15 & 0.07 & 0.23 & 0.18 \\
\hline KK & 0.12 & 0.33 & 0.49 & 0.41 & 0.42 & 0.43 & 0.51 & 0.21 & 0.69 & 0.65 & 0.69 & 0.12 & 0.14 & 0.07 & 0.21 & 0.18 \\
\hline$J$ & 0.14 & 0.31 & 0.48 & 0.4 & 0.4 & 0.44 & 0.48 & 0.21 & 0.68 & 0.63 & 0.66 & 0.14 & 0.13 & 0.06 & 0.21 & 0.17 \\
\hline $\mathrm{MM}$ & 0.12 & 0.3 & 0.46 & 0.38 & 0.39 & 0.41 & 0.51 & 0.2 & 0.67 & 0.64 & 0.67 & 0.12 & 0.14 & 0.06 & 0.22 & 0.17 \\
\hline $\mathrm{TT}$ & 0.14 & 0.29 & 0.49 & 0.41 & 0.42 & 0.42 & 0.53 & 0.22 & 0.71 & 0.68 & 0.7 & 0.14 & 0.15 & 0.07 & 0.23 & 0.18 \\
\hline $\begin{array}{l}\text { Rataan } \\
\text { Average }\end{array}$ & 0.13 & 0.29 & 0.48 & 0.39 & 0.41 & 0.41 & 0.55 & 0.22 & 0.72 & 0.69 & 0.71 & 0.14 & 0.15 & 0.07 & 0.23 & 0.18 \\
\hline $\begin{array}{l}\text { Standar deviasi } \\
\text { Standard deviation }\end{array}$ & 0.01 & 0.06 & 0.05 & 0.04 & 0.04 & 0.06 & 0.06 & 0.02 & 0.08 & 0.08 & 0.08 & 0.02 & 0.01 & 0.01 & 0.02 & 0.02 \\
\hline KK/CV $(\%)$ & 8.17 & 19.75 & 11.34 & 11.06 & 10.18 & 15.44 & 11.76 & 10.69 & 11.11 & 11.41 & 10.78 & 11.56 & 9.43 & 16.41 & 9.57 & 10.63 \\
\hline
\end{tabular}

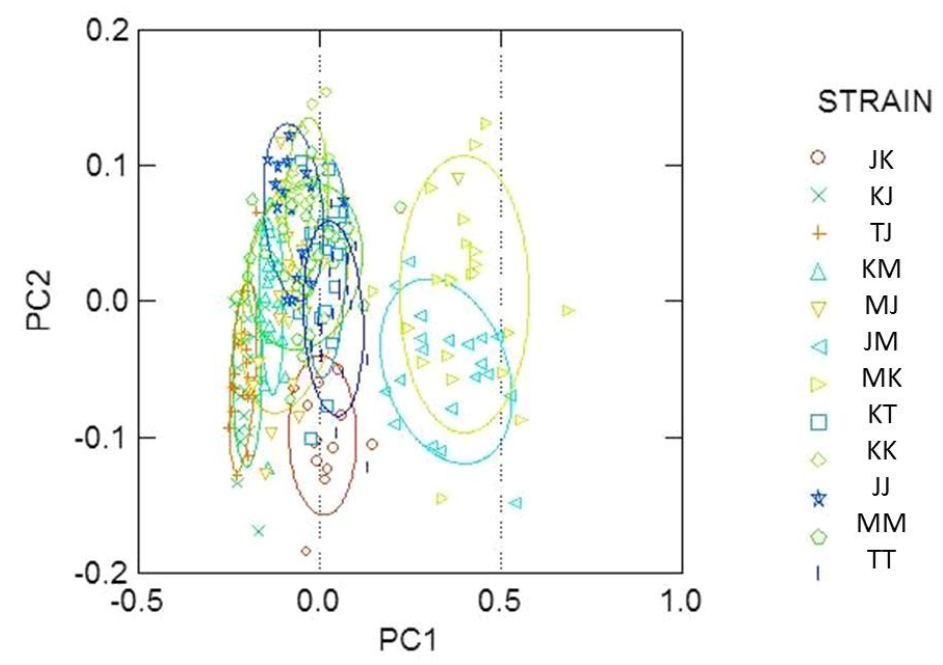

Gambar 2. Diagram pencar skor komponen utama sepanjang komponen utama 1 dan 2 pada 12 populasi ikan gurami menggunakan 16 karakter truss morfometrik; 1. JK, 2. KJ, 3. TJ, 4. KM, 5. MJ, 6. JM, 7. MK, 8. KT, 9. KK, 10. JJ, 11. $M M, 12 . T T$

Figure 2. Scatter plot of Principal Component (PC) scores along the first and second component of 12 populations of giant gourami using 16 truss morphometric characters; 1. JK, 2. KJ, 3. TJ, 4. KM, 5. MJ, 6. JM, 7. MK, 8. KT, 9. KK, 10. JJ, 11. MM, 12. TT 
Populasi JM dan MK pada ikan gurami jantan, berada di sebelah kanan aksis $X$ dan sebelah kanan ordinat $Y$. Karakter populasi JK berada di bawah aksis $X$ dan di bawah aksis Y. Populasi KM berada di bawah aksis $X$ dan di sebelah kanan ordinat Y. Karakter populasi JK,

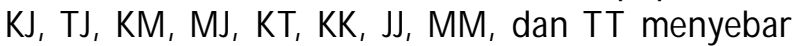
pada garis ordinat $Y$ dan aksis $X$, serta menghimpit ordinat $Y$ (Gambar 3). Populasi JM dan JJ memiliki perbedaan yang sangat jauh pada karakter A-1 dan A-2. Populasi JJ berada pada sumbu positif ordinat $Y$ pada PC2. Populasi JK berada pada sumbu negatifnya. Pada analisis ini, bentuk badan populasi KJ dan TJ cenderung berhimpitan.

Populasi ikan gurami betina JK dan MK terpisah pada sebelah atas dan kanan aksis $Y$ dan ordinat $Y$. Perbedaannya terletak pada karakter A-2 (dahi - pangkal sirip punggung) dan A-3 (pangkal sirip punggung pangkal sirip perut). Semua populasi ikan gurami betina berada di atas aksis $X$ dan di sebelah kanan ordinat Y. Populasi JJ, JK, JM, dan MK memiliki perbedaan pada karakter A-2 dan A-3. Hal tersebut terlihat pada garis yang tidak berhimpitan (Gambar 4).

Indeks kesamaan (sharing component) diamati untuk mengetahui kesamaan atau homogenitas dalam suatu populasi berdasarkan kesamaan ukuran badan tertentu. Indeks kesamaan tertinggi diperoleh pada populasi JJ
$(94,00 \%$ dan MM $(92,00 \%) ;$ sedangkan indeks kesamaan terendah diperoleh pada populasi TJ sebesar $72,00 \%$ (Tabel 4).

Tinggi rendahnya indeks kesamaan sangat dipengaruhi oleh sumber genetik induk yang digunakan sebagai pembentuk strain (Setijaningsih et al., 2007). Selain itu, Suparyanto et al. (1999) mengemukakan bahwa nilai kesamaan ukuran badan memberikan penjelasan adanya percampuran yang terukur antara strain satu dengan strain lainnya. Soewardi (1995) mengemukakan bahwa berdasarkan analisis biokimia enzimatis menggunakan ikan gurami yang berasal dari Parung, strain Bluesafir mempunyai kesamaan struktur genetik yang berdekatan dengan strain Paris dan berjauhan dengan strain Bastar.

Berdasarkan hasil analisis komponen utama di atas selanjutnya dapat dibuat suatu dendrogram yang mengelompokkan populasi-populasi ikan gurami berdasarkan tingkat kemiripan bentuk badan antar populasi. Hasil pengelompokan 12 populasi ikan gurami tersebut dalam bentuk dendrogram disajikan pada Gambar 5.

Berdasarkan pengelompokan pada dendrogram menunjukkan bahwa pada galur murni terdapat dua kelompok (Gambar 5). Kelompok Kalimantan, Majalengka, dan Tasikmalaya mempunyai kekerabatan

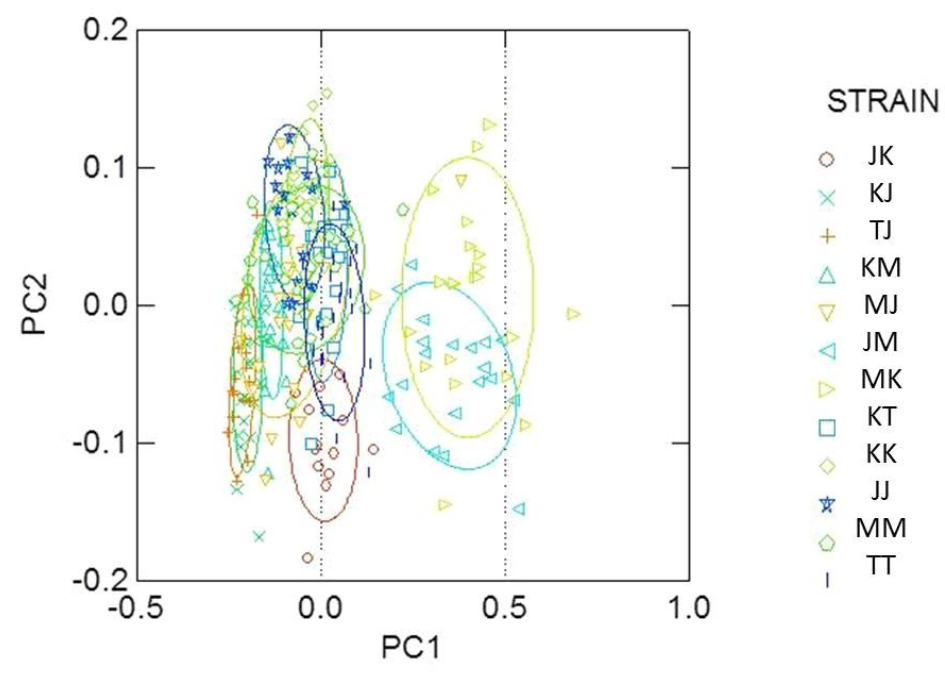

Gambar 3. Diagram pencar skor komponen utama sepanjang komponen utama 1 dan 2 pada 12 populasi ikan gurami jantan (M) menggunakan 16 karakter truss morfometrik; 1 . JK, 2. KJ, 3. TJ, 4. KM, 5. MJ, 6. JM, 7. MK, 8. KT, 9. KK, 10. JJ, 11. $\mathrm{MM}, 12$. TT

Figure 3. Scatter plot of Principal Component (PC) scores along the first and second component of 12 populations of males giant gourami using 16 truss morphometric characters; 1. JK, 2. KJ, 3. TJ, 4. KM, 5. MJ, 6. JM, 7. MK, 8. KT, 9. KK, 10. JJ, 11. MM, 12. TT 


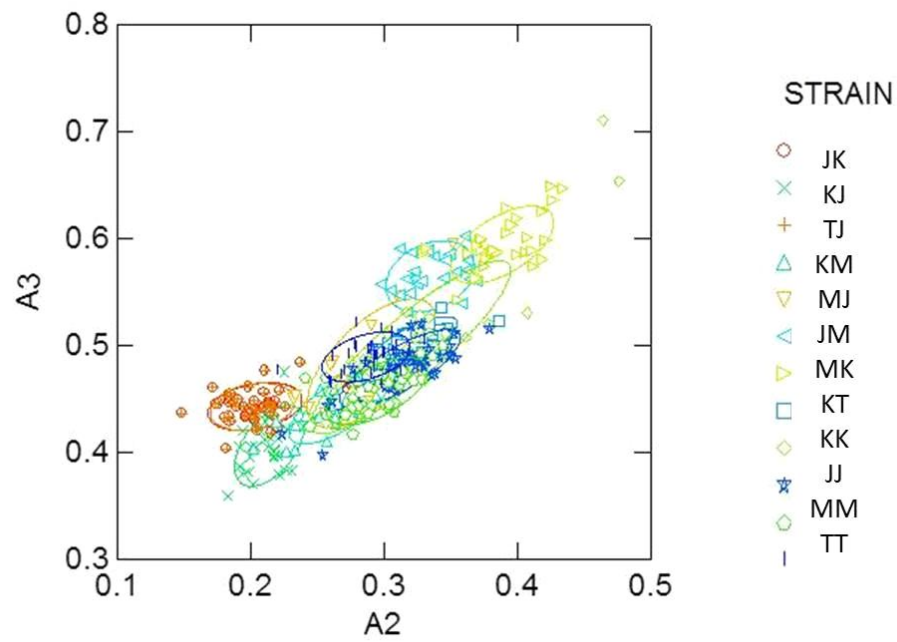

Gambar 4. Diagram pencar skor komponen utama sepanjang komponen utama 2 dan 3 pada 12 populasi ikan gurami betina menggunakan 16 karakter truss morfometrik; 1 . JK, 2. KJ, 3. TJ, 4. KM, 5. MJ, 6. JM, 7. MK, 8. KT, 9. KK, 10. JJ, 11. MM, 12. TT

Figure 4. Scatter plot of Principal Component (PC) scores along the second and third component of 12 populations of females giant gourami using 16 truss morphometric characters; 1. JK, 2. KJ, 3. TJ, 4. KM, 5. MJ, 6. JM, 7. MK, 8. KT, 9. KK, 10. JJ, 11. MM, 12. TT

terdekat, sedangkan Jambi memiliki kekerabatan terjauh. Galur hibrida memiliki dua kelompok, yaitu kelompok satu, yaitu persilangan JM dan MK dan kelompok dua adalah persilangan $\mathrm{KJ}, \mathrm{KM}, \mathrm{JK}, \mathrm{TJ}, \mathrm{MJ}$, dan KT. Populasi galur murni dan persilangan memiliki jarak genetik jauh, sehingga dapat diartikan galur murni dan persilangan itu berbeda (Gambar 5). Pola dendrogram dari jenis kelamin jantan dan betina dapat dilihat pada Gambar 6 dan 7.

Pola dendrogram pada ikan gurami jantan menunjukkan pola yang sama (Gambar 6). Hal yang sama juga terjadi pada pola dendrogram betina (Gambar 7). Gambar 5, 6, dan 7 menunjukkan

Tabel 4. Indeks kesamaan semua populasi

Table 4. Sharing component in all population

\begin{tabular}{ccccccccccccccc}
\hline \multirow{2}{*}{$\begin{array}{c}\text { Populasi } \\
\text { Population }\end{array}$} & \multicolumn{10}{c}{ Indeks kesamaan (Sharing component ) (\% } \\
\cline { 2 - 12 } & JK & KJ & TJ & KM & MJ & JM & MK & KT & KK & J J & MM & TT & \\
\hline JK & 76.00 & 0.00 & 20.00 & 0.00 & 2.00 & 0.00 & 0.00 & 2.00 & 0.00 & 0.00 & 0.00 & 0.00 & 100.00 \\
KJ & 0.00 & 88.00 & 4.00 & 2.00 & 0.00 & 6.00 & 0.00 & 2.00 & 0.00 & 0.00 & 0.00 & 0.00 & 100.00 \\
TJ & 12.00 & 10.00 & 72.00 & 4.00 & 0.00 & 0.00 & 0.00 & 2.00 & 0.00 & 0.00 & 0.00 & 0.00 & 100.00 \\
KM & 0.00 & 4.00 & 0.00 & 92.00 & 2.00 & 0.00 & 0.00 & 2.00 & 0.00 & 0.00 & 0.00 & 0.00 & 100.00 \\
MJ & 0.00 & 4.00 & 2.00 & 2.00 & 84.00 & 4.00 & 2.00 & 2.00 & 0.00 & 0.00 & 0.00 & 0.00 & 100.00 \\
JM & 0.00 & 0.00 & 0.00 & 0.00 & 2.00 & 86.00 & 12.00 & 0.00 & 0.00 & 0.00 & 0.00 & 0.00 & 100.00 \\
MK & 0.00 & 0.00 & 0.00 & 0.00 & 0.00 & 14.00 & 84.00 & 2.00 & 0.00 & 0.00 & 0.00 & 0.00 & 100.00 \\
KT & 0.00 & 0.00 & 0.00 & 2.00 & 10.00 & 0.00 & 0.00 & 88.00 & 0.00 & 0.00 & 0.00 & 0.00 & 100.00 \\
KK & 0.00 & 0.00 & 0.00 & 0.00 & 0.00 & 0.00 & 0.00 & 0.00 & 88.00 & 2.00 & 4.00 & 6.00 & 100.00 \\
JJ & 0.00 & 0.00 & 0.00 & 0.00 & 0.00 & 0.00 & 0.00 & 0.00 & 4.00 & 94.00 & 2.00 & 0.00 & 100.00 \\
M M & 0.00 & 0.00 & 0.00 & 0.00 & 0.00 & 0.00 & 0.00 & 0.00 & 4.00 & 0.00 & 92.00 & 4.00 & 100.00 \\
TT & 0.00 & 0.00 & 0.00 & 0.00 & 0.00 & 0.00 & 0.00 & 0.00 & 4.00 & 2.00 & 4.00 & 90.00 & 100.00 \\
\hline
\end{tabular}




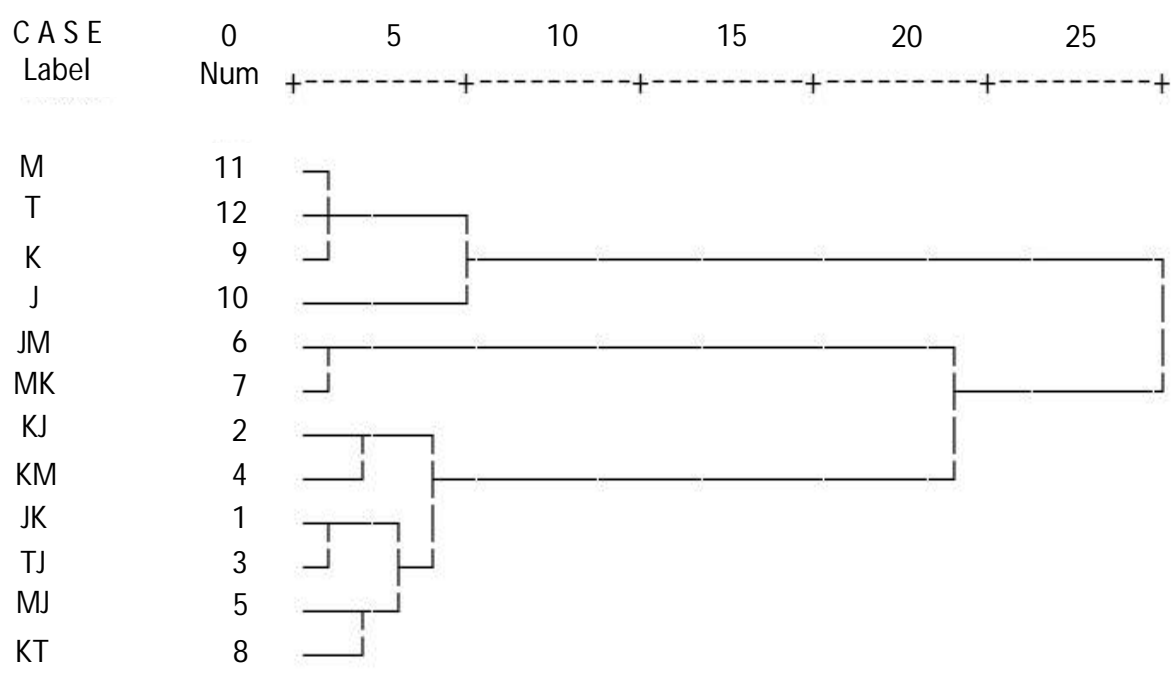

Gambar 5. Dendrogram yang menggambarkan tingkat kemiripan antar populasi ikan gurami menggunakan Program SAS

Figure 5. The dendrogram depicting the morphological similarity among several population of giant gourami using SAS Programe

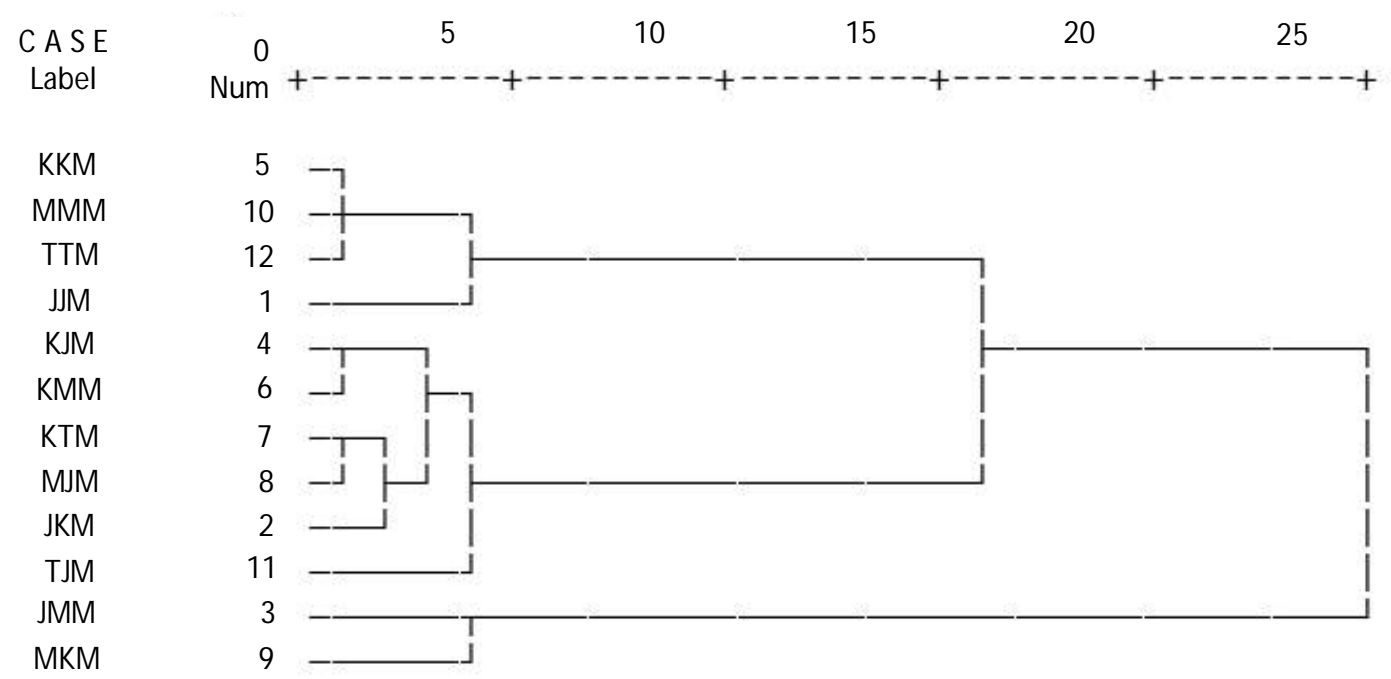

Gambar 6. Dendrogram yang menggambarkan tingkat kemiripan antar populasi jantan (M) ikan gurami menggunakan Program SAS

Figure 6. The dendrogram depicting the morphological similarity among several male population (M) of giant gourami using SAS Programe

konsistensi artinya data gabungan atau dipisah kelamin menunjukkan hal yang sama; galur murni memiliki dua kelompok yaitu kelompok satu adalah: KK, MM, dan TT, serta kelompok dua yaitu galur murni J. Keturunan persilangan juga memiliki dua kelompok. kelompok satu yaitu persilangan JM dan MK, sedangkan kelompok dua adalah persilangan $\mathrm{KJ}, \mathrm{KM}, \mathrm{JK}, \mathrm{TJ}, \mathrm{MJ}$, dan KT.

Secara umum hasil dendrogram menunjukkan bahwa hasil pemijahan galur murni dengan persilangannya berbeda. Hal tersebut terlihat dari jarak genetik yang jauh, sehingga kekerabatannya relatif jauh. Selain itu, terlihat juga pada populasi jantan dan betina (Gambar 6 dan 7). Analisis pengelompokan menggunakan dendrogram ini konsisten dengan hasil analisis diagram pencar di atas. Ikan gurami jantan Jambi diduga memiliki efek dominansi. Hal itu diketahui dari hibridanya membentuk kelompok, namun betina Jambi tidak memiliki efek dominansi, terlihat dari tidak terbentuknya kelompok. 


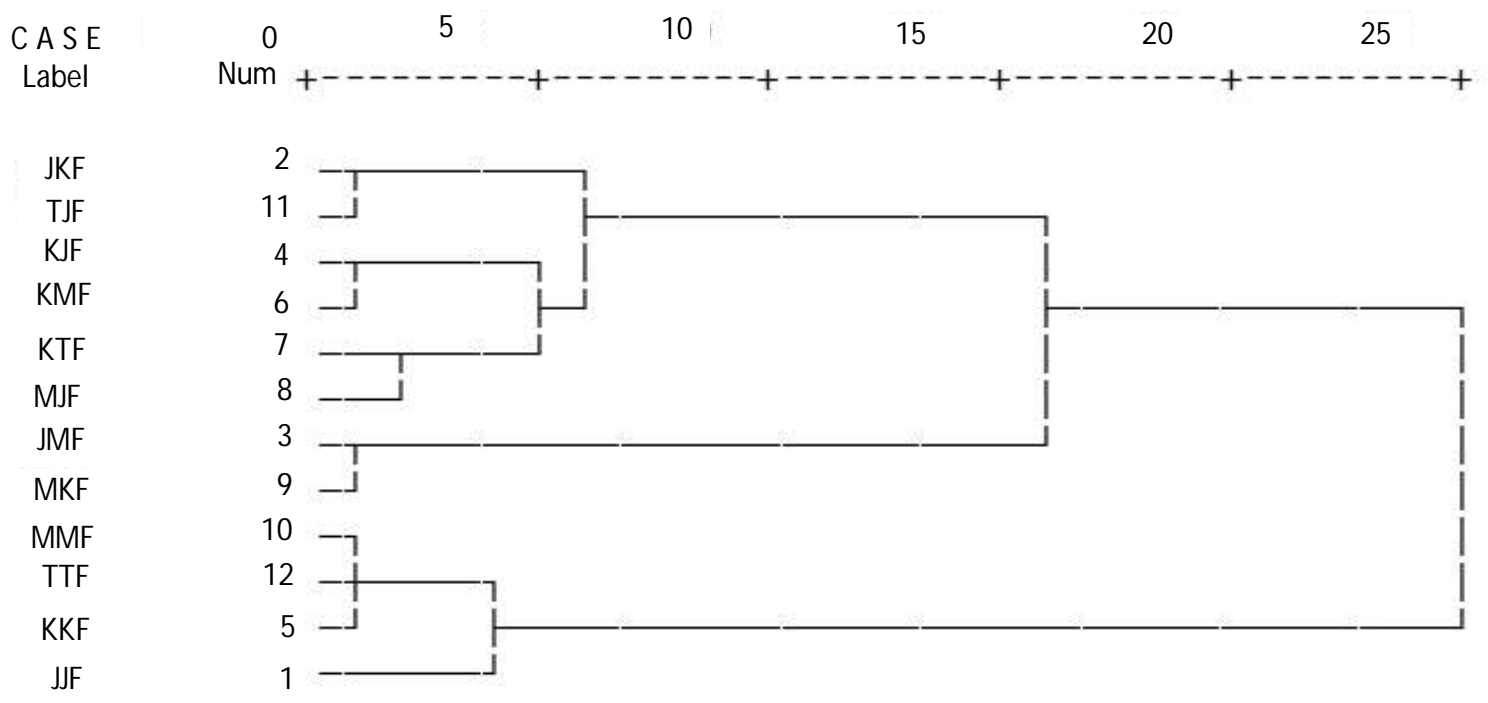

Gambar 7. Dendrogram yang menggambarkan tingkat kemiripan antar populasi betina (F) ikan gurami menggunakan Program SAS.

Figure 7. The dendrogram depicting the morphological similarity amongseveral male population of giant gourami using SAS Programe

\section{KESIMPULAN}

Analisis diagram pencar populasi ikan gurami tanpa melihat jenis kelamin membentuk dua kelompok, yaitu (1) persilangan Jambi x Majalengka, dan Majalengka $x$ Kalimantan dan (2) persilangan Jambi $x$ Kalimantan, Kalimantan x Jambi, Tasikmalaya x Jambi, Kalimantan x Majalengka, Majalengka x Jambi, Kalimantan x Tasikmalaya, galur murni Kalimantan KK, Jambi JJ, Majalengka MM, dan Tasikmalaya TT. Hal tersebut terjadi pula pada populasi jantan. Indeks kesamaan tertinggi diperoleh pada populasi Jambi 94,00\% dan Majalengka (92,00\%; sedangkan indeks kesamaan terendah diperoleh pada populasi Tasikmalaya x Jambi $(72,00 \%$. Berdasarkan bentuk badannya terbentuk empat kelompok besar, yaitu (1) duakelompok pada galur murni menunjukkan populasi galur murni Kalimantan, Majalengka, dan Tasikmalaya kekerabatannya dekat, akan tetapi dengan Jambi memiliki kekerabatan yang jauh. Dua kelompok lainnya pada populasi persilangan, yaitu: persilangan JM dan MK dan kelompok lainnya adalah persilangan KJ, KM, JK, TJ, MJ, dan KT. Populasi galur murni dan persilangan memiliki jarak genetik yang jauh, sehingga populasi galur murni dan persilangan itu berbeda. Populasi ikan gurami Jambi memiliki kekerabatan jauh dengan populasi Kalimantan, Majalengka dan Tasikmalaya. Populasi ikan gurami, Majalengka dan Tasikmalaya memiliki kekerabatan yang dekat. Keturunan hasil persilangan memiliki jarak genetik yang jauh terhadap galur murni.

\section{SARAN}

Bentuk badan ikan akan mengalami perubahan seiring dengan bertambahnya umur dan ukuran badan sehingga karakterisasi pada ukuran yang lebih besar perlu dilakukan untuk mengevaluasi hasil penelitian ini. Selain itu, hasil penelitian ini perlu diverifikasi lebih lanjut melalui karakterisasi molekuler.

\section{UCAPAN TERIMA KASIH}

Diucapkan terima kasih kepada Bapak Sugiyo, Ahmad Sofyan Suri, dan Nurdiansyah sebagai teknisi pada Balai Penelitian Pemuliaan Ikan, Sukamandi yang telah banyak membantu dalam pelaksanaan kegiatan penelitian.

\section{DAFTAR ACUAN}

Ariyanto, D., \& Imron. (2002). Keragaman truss morfometri ikan nila (Oreochromis niloticus) strain 69, GIFT G-3 dan GIFT G-6. J. Pen. Perik. Indonesia, 8(5), 11-18.

Ariyanto, D., Listiyowati, N., \& Imron. (2011). Analisis truss morfometrik beberapa varietas ikan nila (Oreochromis niloticus). J. Ris. Akuakultur, 6(2), 187196.

Bittner, A., Kepler, R., Geisler, P., \& Panatakanjoin, S. (1989). Usaha peningkatan potensi budidaya, produktivitas dan pertumbuhan gurame di Asia Tenggara. Dalam Budidaya Air. Yayasan Obor Indonesia, Jakarta, hlm. 151-174.

Edge, T.A., McAllister, D.E., \& Qadri, S.U. (1991). Meristic and morfometric variation between the 
endangered acadian whitefish, Coregonus hutsmani and the lake whitefish, Coregonus clupeaformis, in the canadian maritim provinces and the state of maine, USA. Can. J. Fish Aquat Sci., 48(11), 2140-2151.

Eknath, A.E., Macaranas, J.M., Agustin, L.Q., Velasco, R.R., Ablan, M.C.A., Pante, M.J.R., \& Pullin, R.S.V. (1991). Biochemical and morphometric approaches to characterize farmed tilapias. ICLARM Quarterly Report. Manila, 14(2), 7-9.

Hubbs, C.L., \& Lagler, K.L. (1958). Fishes of the Great Lakes region, 2nd edition. Cranbrook Institute of Science Bulletin, 26, 1-213.

Imron, Arifin, O.Z., \& Subagyo. (2000). Keragaman truss morfometrik pada ikan mas (Cyprinus carpio) galur Majalaya, Rajadanu Wildandan Sutisna. Prosiding Seminar Penelitian Perikanan 1999/2000. PuslitbangEksplorasi Laut dan Perikanan. Departemen Kelautan dan Perikanan, Jakarta, hlm. 188-197.

Jayasankar, P., Thomas, P.C., Paulton, M.P., \& Mathew, J. (2004). Morphometric and genetic analyzes of Indian mackerel (Rastrelliger kanagurta) from Peninsular India. Asian Fisheries Science, 17, 201-215.

Kusmini, I.I., Hadie, L.E., Hadie, W., \& Kristanto, A.H. (2000). Karakterisasi dalam karakter fenotipe beberapa ras ikan gurame (Osphoronemus gouramy) yang berpotensi dalam budidaya dengan analisis truss morfometrik. Prosiding Simposium Nasional Pengelolaan Plasma Nutfah. Bogor, hlm. 614-620.

Nugroho, E., Satyani D., Kalimah, S., \& Rusmaedi. (1993). Evaluasi potensi genetik dari beberapa ras gurame. Bulletin Penelitian Perikanan Darat, 12(1), 30-36.

Parin, N.V. (1999). [ref. 24867]. Flying-fishes of the genus Prognichthys (Exocoetidae) in the Atlantic Ocean. Voprosy Ikhtiologii v. 39 (no.3): 293-305. [In Russian. English translation in Journal of Ichthyology v. 39(4), 281-293.

Rutaisire, J., Booth, A.J., Masembe, C., Nyakaana, S., $\&$ Muwanika, V.B. (2005). Morphometric and genetic differentiation of two Labeovictorianus populations in Lake Victoria. African Zoology, 40(2), 309317.
Setijaningsih, L., Arifin, O.Z., \& Gustiano, R. (2007). Karakterisasi tiga strain ikan gurami (Osphronemus gouramy Lac.) berdasarkan metode truss morfometrik. J. Iktiologi Indonesia, 7(1), 23-30.

Soewardi, K. (1995). Karakterisasi popuasi ikan gurame (Osphorenemus gouramy Lac) dengan metode biokimia. Jurnal IImu-IImu Perairan dan Perikanan Indonesia, 3(2), 23-31.

Soewardi, K., Rachmawati, R., Affandi, R., \& Bengen, D.G. (1995). Penelusuran varietas ikan gurame (Osphoronemus gouramy Lac.) berdasarkan penampilan karakter Iuar. Jurnal IImu-IImu Perairan dan Perikanan Indonesia, 3(2), 31.

Strauss, R.E., \& Bookstein, F.L. (1982). The truss: body form reconstruction in morphometries. Syst. Zoology, 31, 113-135.

Strauss, R.E., \& Bond, C.E. (1990). Taxonomic methods: morphology. In Shreck, C.B., \& Moyle, C.B. (Eds.). Methods for fish biology American Fisheries Society. Bethesda, Maryland. USA, p. 109-140.

Sudarto. (1989). Porselin, Blue safir dan Paris yang bertelur. Warta Penelitian dan Pengembangan Pertanian, 11(2), 1-2.

Suparyanto, A., Purwadaria, T., \& Subandriyo. (1999). Pendugaan jarak genetik dan faktor peubah pembeda bangsa dan kelompok domba di Indonesia melalui pendekatan analisis morfologi. JITV, 4, 80-87.

Suseno, D., Rusmaedi, Iriana, I., Dharma, L., \& Arifin, O.Z. (2000). Karakterisasi morfologi ikan gurame strain Soang dan Paris. Simposium Nasional Pengelolaan Pemuliaan dan Plasma Nutfah. Bogor, hlm. 589-595.

Swain, D.P., \& Holtby, L.B. (1989). Differences in morphology and behavior between juvenile Coho salmon (Oncorhynchus kisutch) rearing in a lake or in its tributary stream. Can. J. Fish. Aquat. Sci., 46(8), 1,406-1,414.

Swain, D.P., Riddell, B.E., \& Murray, C.B. (1991). Morphological differences between hatchery and wild populations of Coho salmon (Oncorhynchus kisutch): environmental versus genetic origin Can. J. Fish. Aquat. Sci., 48(9), 1,783-1,791.

Winans, G.A. (1984). Multivariate morphometric variability in Pacific salmon: Technical demonstration. Can. J. Fish. Aquat. Sci., 41, 1,150-1,159. 